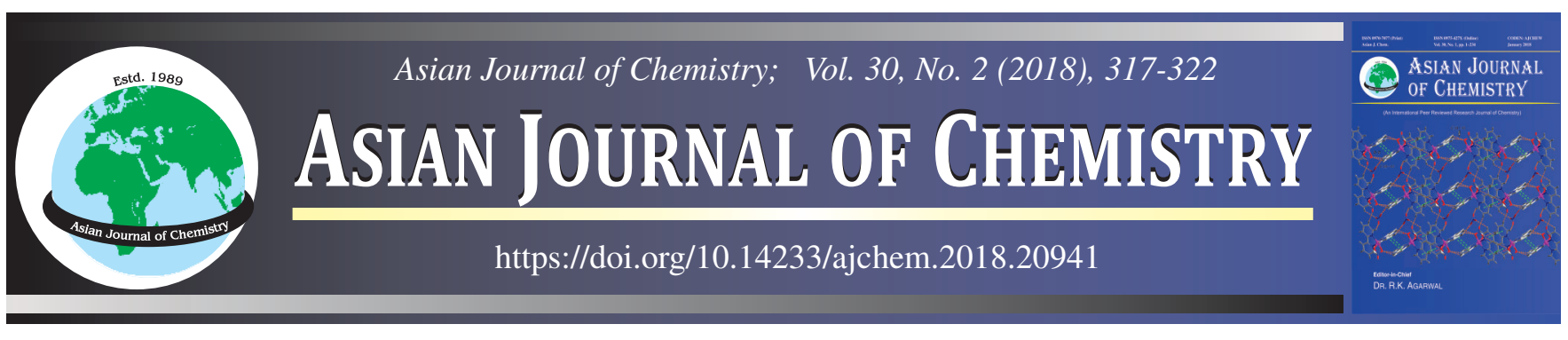

\title{
Initial Proteomic Identification of Secreted Proteins of White-Rot Fungus Porodaedalea pini Grown on Liquid Medium
}

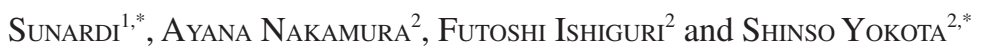

${ }^{1}$ Faculty of Mathematics and Natural Sciences, Lambung Mangkurat University, South Kalimantan 70714, Indonesia

${ }^{2}$ Faculty of Agriculture, Utsunomiya University, Utsunomiya, Tochigi 321-8505, Japan

*Corresponding author: E-mail:sunardi@unlam.ac.id; yokotas@cc.utsunomiya-u.ac.jp

Keywords: Porodaedalea pini, Cellulase, Proteomics, Peptide mass fingerprinting.

\section{INTRODUCTION}

Porodaedalea is a genus of filamentous fungi that belongs to the Hymenochaetaceae and is distributed mainly in North America, East Asia and Europe [1,2]. Porodaedalea pini (syn. Phellinus pini) is a white-rot fungus, which causes white-pocket rot in many conifer species (Pinus, Picea, Abies, Larix, Pseudotsuga and Tsuga), drastically affecting the mechanical properties and reducing the economic value of the wood $[2,3]$. This fungus secretes different kinds of extracellular enzymes and is thus an attractive source of potential medicinal substances, including polysaccharides and ceramides [4-7]. In addition, as this fungus produces extracellular enzymes, especially cellulases, identifying these enzymes is important for potential use in biotechnological applications.

Proteomic analysis is a highly efficient method to rapidly identify proteins in complex mixtures. The strength of proteomic methods resides in the combination of two-dimensional electrophoresis (2-DE) with high resolution and highly sensitive matrix-assisted laser desorption/ionization time-of-flight mass spectrometry (MALDI/TOF/MS) to separate and identify a large number of proteins simultaneously [8]. With the use of this powerful approach, several studies have focused on the analysis of extracellular proteins from fungi, such as Aspergillus flavus and Phanerochaete chrysosporium [9,10]. Advances in mass spectrometric instrumentation and techniques have coincided with the availability of increasing amounts of genomic sequence data. Protein identification is possible by means of peptide mass and fragmentation data generated by mass spectrometric analysis, which is then matched against a database of all possible proteins encoded by a genome sequence [11].

Alfaro et al. [12] have reported comparative analyses of secretome in basidiomycetes, such as white-rot fungi, brownrot fungi and others. Compared with studies on fungal secretomes of white-rot fungi, to date, very limited information is available about the profiles of the secreted proteins of $P$. pini. The aim of the present study was to characterize $P$. pini secreted proteins by means of their enzymatic activities and proteomic approaches. This study is the first to initiate the identification of the secreted proteome of $P$. pini grown in liquid medium by peptide mass fingerprinting using MALDI/TOF/MS. In addition, because this fungus produces important extracellular enzymes, identifying these enzymes is important for their potential use in biotechnological applications.

\section{EXPERIMENTAL}

Fungal material and cultivation conditions: A whiterot fungus, $P$. pini strain WD1174, which was originally provided by the Forestry and Forest Products Research Institute, Tsukuba, Japan, was used in this study. The fungus was pre- 
cultured on potato-dextrose-agar medium in petri dishes $(9$ $\mathrm{cm}$ in diameter) at $26{ }^{\circ} \mathrm{C}$ for 27 days. Ten mycelial disks of 6 $\mathrm{mm}$ diameter were punched out using a cork borer from precultured potato-dextrose-agar plates and used to inoculate 300 $\mathrm{mL}$ Erlenmeyer flasks containing $150 \mathrm{~mL}$ modified Norkrans medium [13]. The composition of the modified Norkrans medium was: $3.00 \mathrm{mM}$ glucose, $16.65 \mathrm{mM}$ asparagine, 18.37 $\mathrm{mM} \mathrm{KH}_{2} \mathrm{PO}_{4}, 5.28 \mathrm{mM} \mathrm{MgSO} \cdot 7 \mathrm{H}_{2} \mathrm{O}, 4.28 \mathrm{mM} \mathrm{NaCl}, 2.25$ $\mathrm{mM} \mathrm{CaCl} 2,0.05 \mathrm{mM} \mathrm{FeCl}_{3} \cdot 6 \mathrm{H}_{2} \mathrm{O}, 770 \mathrm{nM} \mathrm{ZnSO}$, $40 \mathrm{nM}$ thiamine hydrochloride and $1.16 \mathrm{~mL}$ of an additional solution (0.432 $\mathrm{g}$ glucose, $2.144 \mathrm{~g} \mathrm{MgSO}_{4} \cdot 7 \mathrm{H}_{2} \mathrm{O}$ and $3.225 \mathrm{~g}$ urea in $30 \mathrm{~mL} \mathrm{H} \mathrm{H}_{2} \mathrm{O}$ ) and $6.75 \mathrm{~mL}$ hyclone bovine calf serum (GE Healthcare, South Logan, Utah, U.S.A). In addition, $2.2 \%$ (w/v) of Avicel (Funacel II, Funakoshi, Tokyo, Japan) was added to the culture medium as a carbon source. The fungus was cultured under agitation at $100 \mathrm{rpm}$ by a shaker (NR-150, TAITEC Corp., Saitama, Japan) at $24{ }^{\circ} \mathrm{C}$ in the dark.

Preparation of crude enzyme solution: Three flasks containing culture medium were collected every 4 days. The culture medium was filtered through Miracloth (Calbiochem, Darmstadt, Germany) and the filtrates were centrifuged at $1,500 \times \mathrm{g}$ for $15 \mathrm{~min}$ at $4{ }^{\circ} \mathrm{C}$. The protein in the supernatant was precipitated using ammonium sulfate precipitation at 70$90 \%$ concentration and then centrifuged at $9,810 \times \mathrm{g}$ for 20 $\min$ at $4{ }^{\circ} \mathrm{C}$. The obtained pellets were dissolved in acetate buffer ( $\mathrm{pH} 4.2$ ) and then dialyzed against $20 \mathrm{mM}$ succinate buffer ( $\mathrm{pH} 5.5$ ) at $7{ }^{\circ} \mathrm{C}$. The obtained solution was used as crude enzyme preparations.

Endoglucanase and exoglucanase were assayed using carboxymethyl cellulose and avicel as substrates, respectively [14]. The reducing sugars were determined by the dinitrosalicylic acid (DNS) method [15]. $\beta$-Glucosidase activity was determined by measuring $p$-nitrophenol released from $p$-nitrophenyl- $\beta$-D-glucopyranoside [14]. Cellobiose dehydrogenase activity was determined using cytochrome $\mathrm{C}$ as the substrate [16]. All enzymes were spectrophotometrically (V-650, Jasco, Tokyo, Japan) assayed in triplicates and enzyme activities were expressed as nkat/mg of enzymes.

Two-dimensional electrophoresis: The protein samples obtained were precipitated with a $10 \%(\mathrm{w} / \mathrm{v}$; final concentration) aqueous solution of trichloroacetic acid (TCA) and then was kept at $-20^{\circ} \mathrm{C}$ for $1 \mathrm{~h}$, followed by centrifugation at $10,000 \times \mathrm{g}$ for $30 \mathrm{~min}$ at $4{ }^{\circ} \mathrm{C}$. The pellets obtained were washed three times with cold acetone and the acetone was removed by evaporation using nitrogen gas. The dried samples were resuspended in a solubilizing buffer containing $7 \mathrm{M}$ urea, $2 \mathrm{M}$ thiourea, $4 \%$ (w/v) CHAPS (GE Healthcare, Buckinghamshire, England), $20 \mathrm{mM}$ DTT and $2 \%$ (v/v) IPG Buffer (pH 3-10, GE Healthcare) in ultra-pure water. The suspension was centrifuged at $10,000 \times \mathrm{g}$ for $30 \mathrm{~min}$ at $4{ }^{\circ} \mathrm{C}$ and the supernatant was collected in a $1.5 \mathrm{~mL}$ micro tube (Eppendorf, Hamburg, Germany).The protein solution was desalted using a MicroSpin G-25 column (GE Healthcare). The protein concentration of the samples was determined by the Bradford method using ovalbumin (SigmaAldrich, St. Louis, MO, U.S.A.) as the standard [17]. The obtained samples were stored at $-20{ }^{\circ} \mathrm{C}$ before use.

Isoelectric focusing was performed using IPG strips (Immobiline Dry Strip pH 3-10, 13 cm, GE Healthcare) and an Ettan IPGphor unit (GE Healthcare). A $250 \mu \mathrm{g}$ protein sample was focused at $75 \mathrm{kVh}$ with four step voltages from 500 to $8,000 \mathrm{~V}$. The second dimension electrophoresis was performed on a $12.5 \%$ polyacrylamide gel using a Hoefer SE600 Ruby apparatus (GE Healthcare). After 2-DE, the gels were stained with Coomassie brilliant blue G-250 and the gel images were acquired using a scanner (GT-9700, Epson, Tokyo, Japan). The spot detection, spot edition and gel-to-gel matching were performed using Image Master 2D Platinum ver. 5.0 software (GE Healthcare).

The specifically expressed protein spots in the gel were selected and excised from Coomassie brilliant blue-stained gels. The in-gel digestion of the protein spots was carried out with trypsin (Promega, Madison, WI, U.S.A), which was performed according to the method of Shevchenko et al. [18]. MALDI/TOF/MS analyses were performed using an Autoflex II mass spectrometer (Bruker Daltonics GmbH, Bremen, Germany). Analyses were carried out with the matrix solution: $\alpha$-cyano-4-hydroxycinnamic acid (CHCA) saturated in acetonitrile/water $(1: 1, \mathrm{v} / \mathrm{v})$ containing $0.1 \%$ TCA. In each case, $0.5 \mu \mathrm{L}$ of the analyte solution and $0.5 \mu \mathrm{L}$ of the matrix solution were deposited and thoroughly mixed on a Anchor Chip (Bruker Daltonic GmbH). For peptide mass fingerprinting analysis, positively charged ions in the mass-to-charge $(\mathrm{m} / \mathrm{z})$ range of 600-3,000 Da were analyzed in the reflector mode with the laser energy set at $46 \%$. The spectra were processed with Autoflex II analysis software (Bruker Daltonic GmbH). To identify proteins, the search of peptide mass fingerprinting was performed against databases (NCBI non-redundant and SwissProt) using the Mascot search engine (http:// www.matrixscience.com; Fungi Taxonomy used). Database searches were performed with the following parameters: peptides were derived from enzymatic cleavage with trypsin and one missed cleavage was allowed. Carboxamidomethylation of cysteine was set as fixed and oxidation of methionine was set as a variable modification. Peptide mass tolerance was set to $0.5 \mathrm{Da}$ and the peptide mass value set as the $\mathrm{MH}^{+}$and monoisotopic mass. Proteins were identified with the value-based scoring system that transforms the commonly used parameters (pI, molecular mass, percent sequence coverage, number of peptide matched and significance score) into a value-based score for an objective evaluation of protein identification using peptide mass fingerprinting [19].

\section{RESULTS AND DISCUSSION}

Enzyme assays: When $P$. pini was grown in liquid modified Norkrans medium containing microcrystal cellulose as the carbon source, various types of cellulases were produced. Fig. 1 shows the time-course changes of cellulase activities. Based on the results, the activity of $\beta$-glucosidase was the highest among the cellulase activities tested. The $\beta$-glucosidase activity increased with increasing cultivation time and reached a maximum level on the $28^{\text {th }}$ day. Cellobiose dehydrogenase was the second highest cellulase produced by $P$. pini and its production pattern was similar to that of $\beta$-glucosidase. The endoglucanase and exoglucanase activities were relatively low. The results show that $P$. pini produces $\beta$-glucosidase as the major glycoside hydrolase. 

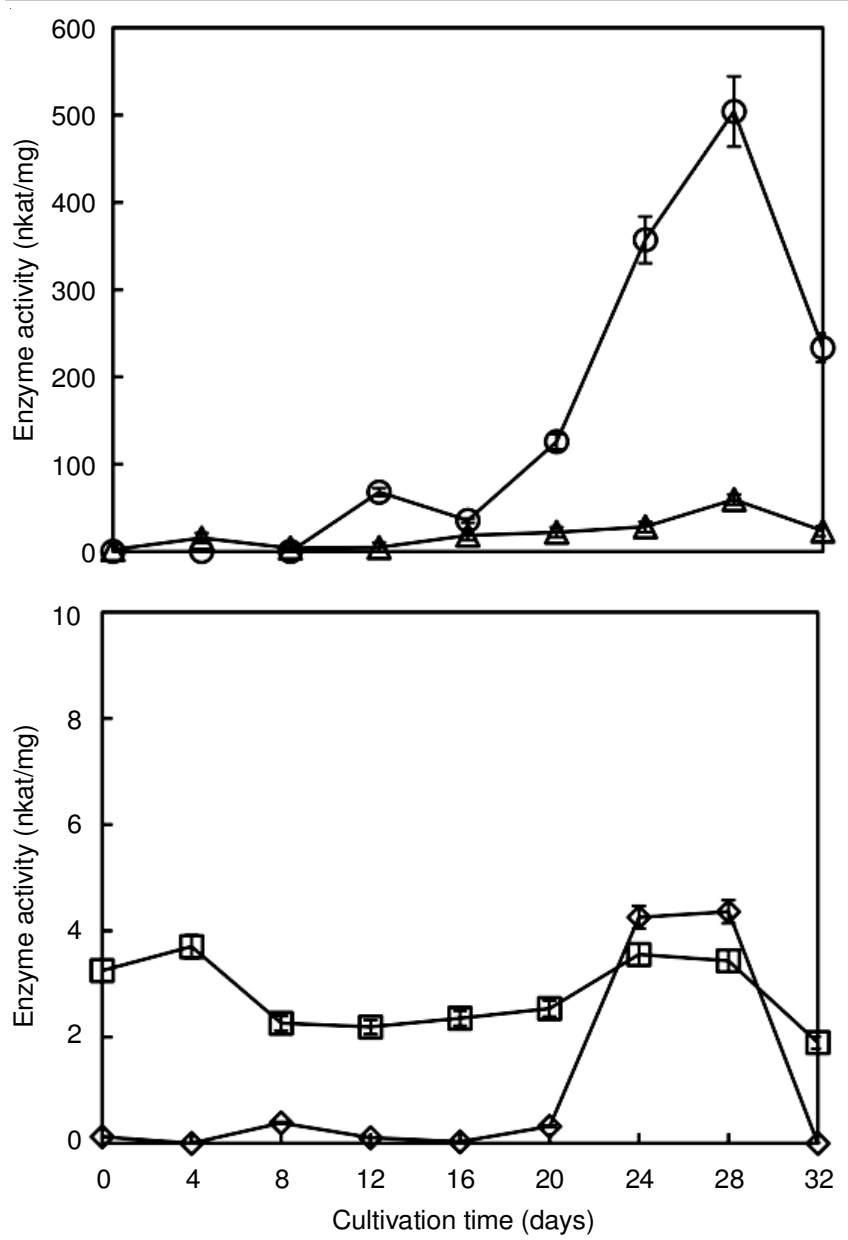

Fig. 1. Time course changes in cellulase activities of $P$. pini WD 1174 grown in modified Norkrans medium with microcrystal cellulose as a carbon source. Symbols: $\bigcirc=\beta$-Glucosidase, $\Delta=$ Cellobiose dehydrogenase, $\diamond=$ Endoglucanase, $\square=$ Exoglucanase. Assays were performed in triplicate. Bars represent the standard deviations

Two dimensional electrophoresis and protein identification: The expression pattern of protein spots at various incubation times of $P$. pini was similar with only minor differences in the number of spots. The protein spots were located in the pI range of 3.0 to 9.5 . Most of the expressed proteins had molecular masses $<75 \mathrm{kDa}$ and were detected in the range of pI 5.0-7.0. The total average numbers of detected protein spots were $415,370,375,410,446$ and 426 on the $8^{\text {th }}, 16^{\text {th }}$, $20^{\text {th }}, 24^{\text {th }}, 28^{\text {th }}$ and $32^{\text {nd }}$ day of incubation, respectively.

Considering the number of protein spots and the level of cellulase activity, we collected the specifically expressed proteins on the $28^{\text {th }}$ day of incubation to identify those proteins. Fig. 2 shows the 2-DE profile of the expressed protein spots of $P$. pini grown in modified Norkrans medium for 28 days. Twenty-eight specifically expressed protein spots were excised, in-gel-digested with trypsin and analyzed with MALDI/TOF/ MS. Twenty-seven proteins were successfully identified by peptide mass fingerprinting using the MASCOT software. For some proteins, the homology was confirmed by the presence of a conserved domain in the known protein matching the deduced sequences of the peptides obtained from 2-DE. The specific proteins identified are presented in Table-1. Particular proteins were detected in the 2-DE gels at each cultivation time point taken and were identified as bovine calf albumin added

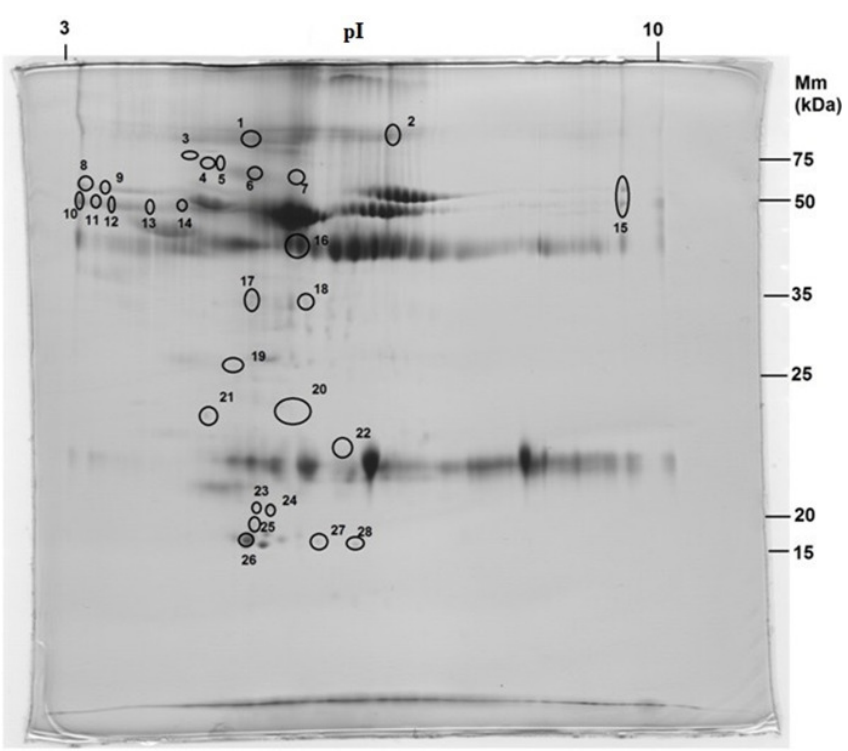

Fig. 2. Coomassie brilliant blue-stained 2-DE gel of the secreted proteins from $P$. pini grown in modified Norkrans medium containing microcrystalline cellulose as the carbon source on the $28^{\text {th }}$ day of incubation using an IPG strip $\mathrm{pH}$ 3-10. The identified protein spots were numbered in order

to the modified Norkrans medium and these protein spots were excluded from further proteome analysis. The identified proteins were classified into the following categories according to their biochemical roles: carbohydrate transport and metabolism (4 proteins), amino acid transport and metabolism (7 proteins), aromatic compound metabolism and oxidative stress responses ( 2 proteins), cellular processes and signaling (5 proteins) and hypothetical or unclassified proteins (9 proteins).

The proteins in the carbohydrate transport and metabolism categories are related to the secretion of hydrolytic enzymes. Of these, spot no. 7 protein was homologous to the glycoside hydrolase family 1 (gil751672663). Fig. 3 shows the identification of glycoside hydrolase family 1 . An indication of the matching quality of these data to the database is evident for the example of glycoside hydrolase family 1 . The experimental and the calculated $\mathrm{pI}$ and molecular mass of spot no. 7 protein were similar to the relatively high number of matching peptides and homologous sequence coverage (16\%) with the enzyme. Glycoside hydrolase family 1 is characterized with a retaining glycosidase mechanism and the most common enzymatic activities for this enzyme are $\beta$-glucosidases and $\beta$-galactosidases, whereas many $\beta$-glucosidases from filamentous fungi are categorized into glycoside hydrolase family 1 [20,21]. This result was confirmed by the high activity of $\beta$-glucosidase produced by this fungus (Fig. 1).

Some other proteins were identified as 3-O- $\alpha$-D-mannopyranosyl- $\alpha$-D-mannopyrano-sexylosylphosphotransferase (spot no. 2), mannitol-1-phosphate 5-dehydrogenase (spot no. 9) and xylulose kinase (spot no. 11), respectively, which are thought to play important roles in carbohydrate metabolism. The 3-O- $\alpha$-D-mannopyranosyl- $\alpha$-D-mannopyranosexylosylphosphotransferase is a specific enzyme for UDP-xylose and for the mannose acceptor to form a xylose-1-phosphate-6mannose linkage. This enzyme was also identified in Heterobasidiomycetes Cryptococcus neoformans [22]. Mannitol-1- 
IDENTIFIED SPECIFIC PROTEINS FROM Porodaedalea pini GROWN IN MODIFIED NORKRANS MEDIUM FOR 28 d BY PEPTIDE MASS FINGER-PRINTING

\begin{tabular}{|c|c|c|c|c|c|c|c|c|}
\hline $\begin{array}{l}\text { Spot } \\
\text { No. }\end{array}$ & Accession database $^{a}$ & Protein name & Organism & $\begin{array}{l}\mathrm{Mm}^{\mathrm{b}} \\
(\mathrm{Da})\end{array}$ & $\mathrm{pI}^{\mathrm{c}}$ & $\begin{array}{l}\text { Matching } \\
\text { peptides }\end{array}$ & $\begin{array}{l}\text { SeqCov }^{d} \\
(\%)\end{array}$ & Function \\
\hline 1 & PUS1_SCHPO (S) & tRNApseudouridine synthase 1 & $\begin{array}{l}\text { Schizosaccharomyces } \\
\text { pombe }\end{array}$ & 60685 & 6.28 & 10 & 13 & $\begin{array}{l}\text { Amino acid transport and } \\
\text { metabolism }\end{array}$ \\
\hline 2 & XPT1_CRYGW (S) & $\begin{array}{l}\text { 3- } O \text {-alpha-D-mannopyranosyl- } \\
\text { alpha-D-mannopyranose } \\
\text { xylosylphosphotransferase }\end{array}$ & Cryptococcus gattii & 100284 & 6.31 & 15 & 15 & $\begin{array}{l}\text { Carbohydrate transport and } \\
\text { metabolism }\end{array}$ \\
\hline 3 & $\begin{array}{l}\text { gil573027269 } \\
(\mathrm{N})\end{array}$ & $\begin{array}{l}\text { Hypothetical protein } \\
\text { PaG_05364 }\end{array}$ & Pseudozyma aphidis & 110573 & 5.34 & 13 & 8 & Unclassified \\
\hline 5 & $\begin{array}{l}\text { gil751174362 } \\
(\mathrm{N})\end{array}$ & $\begin{array}{l}\text { Hypothetical protein } \\
\text { M378DRAFT_26578 }\end{array}$ & Amanita muscaria & 62389 & 6.17 & 12 & 9 & Unclassified \\
\hline 6 & gil401886540 (N) & Polyadenylate-binding protein & Trichosporon asahii & 74124 & 6.02 & 10 & 10 & $\begin{array}{l}\text { Amino acid transport and } \\
\text { metabolism }\end{array}$ \\
\hline 7 & gil751672663 (N) & $\begin{array}{l}\text { Glycoside hydrolase family } 1 \\
\text { protein }\end{array}$ & Serendipita vermifera & 70043 & 6.02 & 13 & 16 & $\begin{array}{l}\text { Carbohydrate transport and } \\
\text { metabolism }\end{array}$ \\
\hline 9 & $\begin{array}{l}\text { MTLD_NEUCR } \\
\text { (S) }\end{array}$ & $\begin{array}{l}\text { Mannitol-1-phosphate 5- } \\
\text { dehydrogenase }\end{array}$ & Neurospora crassa & 44630 & 5.32 & 4 & 6 & $\begin{array}{l}\text { Carbohydrate transport and } \\
\text { metabolism }\end{array}$ \\
\hline 11 & XKS1_SCHPO (S) & Xylulose kinase & $\begin{array}{l}\text { Schizosaccharomyces } \\
\text { pombe }\end{array}$ & 62158 & 5.77 & 5 & 6 & $\begin{array}{l}\text { Carbohydrate transport and } \\
\text { metabolism }\end{array}$ \\
\hline 12 & ADH2_YARLI (S) & Alcohol dehydrogenase & Yarrowia lipolytica & 37804 & 6.32 & 9 & 20 & $\begin{array}{l}\text { Aromatic compound metabolism } \\
\text { and oxidative stress responses }\end{array}$ \\
\hline 13 & gil729704134 (N) & $\begin{array}{l}\text { Putative heat shock transcription } \\
\text { factor }\end{array}$ & Rhizopus microsporus & 46157 & 6.14 & 10 & 16 & Cellular processes and signaling \\
\hline 14 & gil358368251 (N) & BTB domain transcription factor & Aspergillus kawachii & 51359 & 4.82 & 8 & 12 & Cellular processes and signaling \\
\hline 15 & gil302675356(N) & $\begin{array}{l}\text { Hypothetical protein } \\
\text { SCHCODRAFT_113784 }\end{array}$ & Schizophyllum commune & 44901 & 9.95 & 9 & 12 & Unclassified \\
\hline 16 & $\begin{array}{l}\text { gil672381788 } \\
(\mathrm{N})\end{array}$ & $\begin{array}{l}\text { Hypothetical protein } \\
\text { MANI_020714 }\end{array}$ & Metarhizium anisopliae & 52222 & 5.75 & 8 & 11 & Unclassified \\
\hline 17 & gil213406217 (N) & Rho family GTPase Rho5 & $\begin{array}{l}\text { Schizosaccharomyces } \\
\text { japonicus }\end{array}$ & 22760 & 5.99 & 9 & 16 & Cellular processes and signaling \\
\hline 18 & SSN8_ASPFU (S) & $\begin{array}{l}\text { RNA polymerase II } \\
\text { holoenzymecyclin-like subunit }\end{array}$ & Neosartorya fumigata & 34645 & 7.12 & 4 & 11 & $\begin{array}{l}\text { Amino acid transport and } \\
\text { metabolism }\end{array}$ \\
\hline 19 & $\begin{array}{l}\text { gil562972804 } \\
\text { (N) }\end{array}$ & $\begin{array}{l}\text { Hypothetical protein } \\
\text { HPODL_04162 }\end{array}$ & $\begin{array}{l}\text { Ogataea } \\
\text { parapolymorpha }\end{array}$ & 33181 & 4.96 & 10 & 21 & Unclassified \\
\hline 21 & gil425766525 (N) & Acetyltransferase & Penicillium digitatum & 23428 & 5.51 & 8 & 18 & Cellular processes and signaling \\
\hline 22 & gil628282349(N) & $\begin{array}{l}\text { Hypothetical protein } \\
\text { A1O7_01945 }\end{array}$ & $\begin{array}{l}\text { Cladophialophora } \\
\text { regresi }\end{array}$ & 23101 & 7.74 & 8 & 19 & Unclassified \\
\hline 23 & $\begin{array}{l}\text { SPC25_DEBHA } \\
\text { (S) }\end{array}$ & $\begin{array}{l}\text { Probable kinetochore protein } \\
\text { SPC } 25\end{array}$ & Debaryomyces hansenii & 26699 & 4.79 & 8 & 16 & $\begin{array}{l}\text { Amino acid transport and } \\
\text { metabolism }\end{array}$ \\
\hline 24 & FKBP_KLULA (S) & FK506-binding protein 1 & $\begin{array}{l}\text { Saccharomyces } \\
\text { cerevisiae }\end{array}$ & 12207 & 5.72 & 4 & 30 & Cellular processes and signaling \\
\hline 25 & gil342320603 (N) & $\begin{array}{l}\text { Aflatoxin biosynthesis } \\
\text { ketoreductase nor-1 }\end{array}$ & Rhodotorula glutinis & 29974 & 7.05 & 8 & 17 & $\begin{array}{l}\text { Amino acid transport and } \\
\text { metabolism }\end{array}$ \\
\hline 26 & gil552920312 (N) & $\begin{array}{l}\text { Hypothetical protein } \\
\text { GLOINDRAFT_230452 }\end{array}$ & Rhizophagus irregularis & 22738 & 6.85 & 6 & 25 & Unclassified \\
\hline 27 & IF4E_ASHGO (S) & $\begin{array}{l}\text { Eukaryotic translation initiation } \\
\text { factor } 4 \mathrm{E}\end{array}$ & Ashbya gossypii & 24010 & 5.35 & 4 & 11 & $\begin{array}{l}\text { Amino acid transport and } \\
\text { metabolism }\end{array}$ \\
\hline 28 & gil444315103 (N) & $\begin{array}{l}\text { Hypothetical protein } \\
\text { TBLA_0A09020 }\end{array}$ & Tetrapisispora blattae & 21829 & 6.19 & 8 & 29 & Unclassified \\
\hline
\end{tabular}

phosphate 5-dehydrogenase is a key enzyme in the mannitol cycle, which is commonly found in white-rot basidiomycetes such as Phanerochaete crysosporium and Pleurotus ostreatus $[23,24]$. In this cycle, fructose-6-phosphate produced in the glycolytic pathway is converted to mannitol-1-phosphate by this enzyme, which is further dephosphorylated to mannitol $[23,24]$. Xylulose kinase plays an important role in xylose metabolism, which has also been identified in many fungi such as Saccharomyces cerevisiae [25]. Xylulose is phosphorylated to xylulose-5-phosphate by xylulose kinase before it enters into the glycolytic pathway through the non-oxidative pentose phosphate pathway [25]. This step is common in fungi and important because xylose is one of the major components of hydrolysates of hemicelluloses.
Two proteins, spots no. 12 and 20, were identified as alcohol dehydrogenase and glutathione S-transferase, respectively, being related to aromatic compound metabolism and defence agains oxidative stress $[23,26]$. White-rot fungi use and regulate unique metabolic protein for degrading a variety of aromatic compounds, such as alcohol dehydrogenase and glutathione $S$-transferase $[10,23,27]$. These proteins play an important role in cleavage of the $\beta$-aryl ether linkage of high molecular lignin [28] and support lignin degradation; although, the precise mechanisms of these enzymes remain unresolved [10,29]. Previous studies have demonstrated that $P$. pini simultaneously degrades lignin and cellulose during the wood decay process [4].

Based on the enzyme assay, some other hypothetical/ unidentified proteins appear to correspond to other cellulases 


\section{A) \\ Spot no. 7 matched to: gil751672663 Score: 48 Expect: 89 \\ Glycoside hydrolase family 1 protein [Serendipita vermifera]}

Nominal mass (Mm): 70043 Da; Calculated pI value: 6.02

Variable modification: Carbamidomethyl (C)

Cleavage by Tripsin: cuts C-term side of KR unless next residue is $\mathbf{P}$

Number of mass value searched: $\mathbf{4 1}$

Number of mass value matched: $\mathbf{1 3}$

Sequence coverage: $\mathbf{1 6 \%}$

Matched peptides shown in Bold

\begin{tabular}{|c|c|c|c|c|c|}
\hline 1 & MAI & ASF & VDVDG & DFS & RT \\
\hline 51 & NGDVATDSYR & LWREDIALLK & QYGIRAYRFS & IAWSRIIPLG & GRNDPVNPKG \\
\hline 01 & IKFYSDVIDE & LLKAGITPFV & TLYHWDLPQE & LHDRYGGWLN & DYVN \\
\hline 51 & SFG & DRVKHWLTLN & EPW & GRGVFAPGRC & EGD \\
\hline 01 & SSTEP & NLJ & KPT & QQGQIGITLN & DNS \\
\hline 51 & PENI & & PV & GNRLP & DFt \\
\hline 01 & KGSS & TY1 & GSI & YTFT & SWL \\
\hline 51 & QTYPEGFRAL & NKRYKL & PIYVT & OSLPIE & RVE \\
\hline 01 & YFRG & KAMYEDGVDI & RSYFPWSFLD & NFEWADGYGT & RFGVTYVDYK \\
\hline 51 & KESA & KFLIKWFREH & QEQEPGSTTP & LLSALPSPTP & ENLSTHTLAE \\
\hline 501 & GP & SPASNGVWKC & PLKLENGRVC & HHEIANGEKG & SVAEHFEWHL \\
\hline & & ELTLIESASP & VKEVPAAHAT & ESKASTPRAV & NKASPVAEKK \\
\hline & & & & & \\
\hline
\end{tabular}

B)

\begin{tabular}{crrrrll}
\hline Start - End & Observed & Mr $($ expt $)$ & Mr(calc) & Delta & M & Peptide \\
\hline $1-6$ & 752.02 & 751.01 & 751.37 & -0.36 & 1 & MAMQKK \\
$51-60$ & 1097.91 & 1096.91 & 1096.48 & 0.43 & 0 & NGDVATDSYR \\
$183-189$ & 703.75 & 702.74 & 702.38 & 0.36 & 0 & GVFAPGR \\
$284-301$ & 2116.17 & 2115.17 & 2115.08 & 0.08 & 1 & MLGNRLPDFTPEEWALVK \\
$359-366$ & 1006.58 & 1005.57 & 1005.56 & 0.01 & 0 & ALLNYYWK \\
$399-403$ & 713.84 & 712.83 & 712.35 & 0.47 & 0 & VEYFR \\
$404-421$ & 2017.59 & 2016.59 & 2016.95 & -0.36 & 1 & GATESLYKAMYEDGVDIR \\
$404-421$ & 2034.34 & 2033.33 & 2032.94 & 0.39 & 1 & GATESLYKAMYEDGVDIR \\
$520-528$ & 1086.3360 & 1085.33 & 1085.57 & -0.24 & 1 & CPLKLENGR \\
$593-599$ & 701.1782 & 700.179 & 700.38 & -0.21 & 0 & ASPVAEK \\
$601-607$ & 735.9274 & 734.921 & 735.36 & -0.44 & 0 & AGTWSSK \\
$608-613$ & 825.09 & 824.09 & 824.40 & -0.31 & 1 & FRDTMR \\
$608-613$ & 841.09 & 840.09 & 840.39 & -0.30 & 1 & FRDTMR \\
\hline
\end{tabular}

Fig. 3. Peptide mass fingerprinting of the spot no. 7 protein and identification of the conserved domains. Notes: A) Sequence of the Serendipita vermifera glycoside hydrolase family 1 protein (gil751672663) found to be homologous to spot no. 7 protein. Matched peptides are shown in bold. B) Sequences of the digested peptides obtained. Start-End $=$ amino acid position indicating the portion of the known protein matching the peptide deduced sequence, Observed = experimental $\mathrm{m} / \mathrm{z}$ value, $\mathrm{Mr}(\mathrm{expt})=$ experimental $\mathrm{m} / \mathrm{z}$ value transformed to a relative molecular mass, $\mathrm{Mr}(\mathrm{calc})=$ calculated relative molecular mass of the matched peptide, Delta $=$ difference (error) between the experimental and calculated mass, $\mathrm{M}=$ number of missed enzyme cleavage sites and Peptide = sequence of the peptide in oneletter code

(endoglucanase, exoglucanase and cellobiose dehydrogenase). There are some possible reasons why these protein spots could not be identified as extracellular cellulases. Most extracellular filamentous fungal proteins are highly glycosylated and are therefore difficult to identify by peptide mass finger-printing because of resistance to proteolysis [30,31]. Glycosylation of secreted proteins by fungi provides the proteins with additional stability and resistance to environmental effects such as $\mathrm{pH}$, 
heat and proteolytic attack, as well as solubilization of the proteins in the culture medium. To identify these proteins, sequence tag methods using liquid chromatography tandem mass spectroscopy (LC-MS/MS) should be used in future investigations.

\section{Conclusion}

To our best of knowledge, this is the first report describing proteomic analysis of secreted proteins by $P$. pini grown in a liquid medium. Enzyme assays confirmed that $\beta$-glucosidase activity was the highest among the enzymes produced by this fungus. Twenty seven expressed proteins were identified on the $28^{\text {th }}$ day of incubation by proteomic analysis. In addition, one spot of the proteins in the carbohydrate transport and metabolism categories was found to be related to hydrolytic enzyme. This protein was homologous to the glycoside hydrolase family 1.

\section{REFERENCES}

1. M. Tomsovsk, P. Sedlák and L. Jankovsk, Mycol. Prog., 9, 225 (2010) https://doi.org/10.1007/s11557-009-0628-y.

2. W. Szewczyk, H. Kwasna, J.B. Borowczyk and M.B. Wasilewska, Cent. Eur. J. Biol., 9, 614 (2014);

https://doi.org/10.2478/s11535-014-0293-2.

3. W.A. Ayer, D.J. Muir and P. Chakravarty, Phytochemistry, 42, 1321 (1996);

https://doi.org/10.1016/0031-9422(96)00125-2.

4. Sunardi, J. Tanabe, F. Ishiguri, J. Ohshima, K. Iizuka and S. Yokota, Int. Biodeterior. Biodegrad., 110, 108 (2016); https://doi.org/10.1016/j.ibiod.2016.02.022

5. C.Y. Liew, A. Husaini, H. Hussain, S. Muid, K.C. Liew and H.A. Roslan, World J. Microbiol. Biotechnol., 27, 1457 (2011); https://doi.org/10.1007/s11274-010-0598-X.

6. M. Jaszek, K. Kos, A. Matuszewska, M. Graz, D. Stefaniuk, M. OsiñskaJaroszuk, M. Prendecka, E. Józwik and K. Grzywnowicz, Appl. Biochem. Biotechnol., 174, 644 (2014);

https://doi.org/10.1007/s12010-014-1064-2.

7. P. Jiang, L. Yuan, D. Cai, L. Jiao and L. Zhang, Carbohydr. Polym., 117, 600 (2015);

https://doi.org/10.1016/j.carbpol.2014.10.013.

8. P.-W. Chu, M.-N. Yap, C.-Y. Wu, C.-M. Huang, F.-M. Pan, M.-J. Tseng and S.-T. Chen, Electrophoresis, 21, 1740 (2000); https://doi.org/10.1002/(SICI)1522-2683(20000501)21:9<1740::AIDELPS1740>3.0.CO;2-N.

9. M.L. Medina, U.A. Kiernan and W.A. Francisco, Fungal Genet. Biol., 41, 327 (2004); https://doi.org/10.1016/j.fgb.2003.11.014.

10. A. Manavalan, S.S. Adav and S.K. Sze, J. Proteomics, 75, 642 (2011); https://doi.org/10.1016/j.jprot.2011.09.001

11. P.A. Haynes, S.P. Gygi, D. Figeys and R. Aebersold, Electrophoresis, 19, 1862 (1998);

https://doi.org/10.1002/elps.1150191104
12. M. Alfaro, J.A. Oguiza, L. Ramirez and A.G. Pisabarro, J. Proteomics, 102, 28 (2014); https://doi.org/10.1016/j.jprot.2014.03.001.

13. B. Norkrans, Symbolae Botanicae Upsalienses, vol. 11, p. 126 (1950).

14. T.M. Wood and K.M. Bhat, Methods Enzymol., 160, 87 (1988); https://doi.org/10.1016/0076-6879(88)60109-1.

15. G.L. Miller, Anal. Chem., 31, 426 (1959); https://doi.org/10.1021/ac60147a030.

16. M. Samejima and K.L. Eriksson, Eur. J. Biochem., 207, 103 (1992); https://doi.org/10.1111/j.1432-1033.1992.tb17026.x.

17. M.M. Bradford, Anal. Biochem., 72, 248 (1976); https://doi.org/10.1016/0003-2697(76)90527-3.

18. A. Shevchenko, M. Wilm, O. Vorm and M. Mann, Anal. Chem., 68, 850 (1996) https://doi.org/10.1021/ac950914h.

19. S. Damodaran, T.D. Wood, P. Nagarajan and R.A. Rabin, Geno. Prot. Bioinfo., 5, 152 (2007); https://doi.org/10.1016/S1672-0229(08)60002-9.

20. P. Ramachandran, M.K. Tiwari, R.K. Singh, J.-R. Haw, M. Jeya and J.-K. Lee, Process Biochem., 47, 99 (2012); https://doi.org/10.1016/j.procbio.2011.10.015.

21. S. Yang, C. Hua, Q. Yan, Y. Li and Z. Jiang, Carbohydr. Polym., 92, 784 (2013); https://doi.org/10.1016/j.carbpol.2012.09.086.

22. M.C. Reilly, S.B. Levery, S.A. Castle, J.S. Klutts and T.L. Doering, J. Biol. Chem., 284, 36118 (2009); https://doi.org/10.1074/jbc.M109.056226.

23. F. Matsuzaki, M. Shimizu and H. Wariishi, J. Proteome Res., 7, 2342 (2008); https://doi.org/10.1021/pr700617s.

24. T.K. Chakraborty, D. Basu, N. Das, S. Sengupta and M. Mukherjee, FEMS Microbiol. Lett., 236, 307 (2004); https://doi.org/10.1111/j.1574-6968.2004.tb09662.x.

25. C. Guo, P. He, D. Lu, A. Shen and N. Jiang, J. Appl. Microbiol., 101, 139 (2006); https://doi.org/10.1111/j.1365-2672.2006.02915 x.

26. C.A. Dowd, C.M. Buckley and D. Sheehan, Biochem. J., 324, 243 (1997); https://doi.org/10.1042/bj3240243.

27. M. Morel, A.A. Ngadin, M. Droux, J. Jacquot and E. Gelhaye, Cell. Mol. Life Sci., 66, 3711 (2009); https://doi.org/10.1007/s00018-009-0104-5.

28. Y. Otsuka, T. Sonoki, S. Ikeda, S. Kajita, M. Nakamura and Y. Katayama, Eur. J. Biochem., 270, 2353 (2003); https://doi.org/10.1046/j.1432-1033.2003.03545.x.

29. E. Masai, A. Ichimura, Y. Sato, K. Miyauchi, Y. Katayama and M. Fukuda, J. Bacteriol., 185, 1768 (2003); https://doi.org/10.1128/JB.185.6.1768-1775.2003.

30. J.F. Peberdy, Trends Biotechnol., 12, 50 (1994); https://doi.org/10.1016/0167-7799(94)90100-7.

31. Y. Liang, L. Pan and Y. Lin, Biosci. Biotechnol. Biochem., 73, 192 (2009); https://doi.org/10.1271/bbb.80500. 